\title{
Morfologi, Patogenesis, dan Imunoterapi Kanker Paru Tipe Adenokarsinoma
}

\author{
Renita Y. Robot, ${ }^{1}$ Meilany F. Durry, ${ }^{2}$ Carla F. Kairupan²
}

\author{
${ }^{1}$ Program Studi Pendidikan Dokter Fakultas Kedokteran Universitas Sam Ratulangi, Manado, \\ Indonesia \\ ${ }^{2}$ Bagian Patologi Anatomi Fakultas Kedokteran Universitas Sam Ratulangi Manado, \\ Indonesia \\ Email: renita.yohana@gmail.com
}

\begin{abstract}
Although some common therapies for cancers are available, many patients experience relapse during therapy. Therefore, an understanding of the pathogenesis of lung adenocarcinomas is needed in lung cancer therapies, especially targeted therapies. Immunotherapy has been shown to be effective in the therapy of various tumors, including non-small cell lung cancer (NSCLC). This study was aimed to review the morphology, pathogenesis, and immunotherapy of lung adenocarcinomas. This was a literature review study using databases of Clinical Key, Pubmed, and Google Scholar. The results showed that morphology of lung adenocarcinomas was characterized by the presence of lesions consisting of several morphological spectra, starting with pre-invasive lesions, then minimally invasive adenocarcinomas to invasive adenocarcinomas. Pathogenesis of lung adenocarcinomas was associated with genetic changes of several genes such as EGFR, KRAS, ALK, and ROS1; however, the most frequently involved were EGFR, KRAS, and ALK. The immunotherapies used for lung adenocarcinomas were nivolumab, pembrolizumab, atezolizumab, tremelimumab, durvalumab, avelumab, cemiplimab, cetuximab, panitumumab, and matuzumab; however, the most commonly used were nivolumab, pembrolizumab, and atezolizumab. In conclusion, morphological spectra of lung adenocarcinomas are pre-invasive lesions, minimally invasive adenocarcinomas, and invasive adenocarcinomas. Pathogenesis of lung adenocarcinomas is associated with the presence of genetic changes, especially mutations of EGFR, KRAS and ALK. The most widely used immunotherapies for lung adenocarcinomas are nivolumab and pembrolizumab, which are included in the PD-1 antibody group and atezolizumab in the PD-L1 antibody group.
\end{abstract}

Keywords: lung adenocarcinoma morphology; pathogenesis; immunotherapy

\begin{abstract}
Abstrak: Telah tersedia beberapa terapi umum kanker namun banyak pasien mengalami kekambuhan saat terapi. Oleh karena itu dibutuhkan pemahaman tentang patogenesis adenokarsinoma paru dalam terapi kanker paru khususnya terapi target. Imunoterapi dianggap sebagai teknologi yang memberikan harapan dan telah terbukti efektif dalam terapi berbagai tumor, termasuk non-small cell lung cancer (NSCLC). Penelitian ini bertujuan untuk menelaah morfologi, patogenesis, dan imunoterapi dari kanker paru tipe adenokarsinoma. Jenis penelitian ialah literature review menggunakan database Clinical Key, Pubmed, dan Google Scholar. Hasil penelitian mendapatkan morfologi adenokarsinoma paru ditandai adanya lesi yang terdiri dari beberapa spektrum morfologik, diawali dengan lesi preinvasif, selanjutnya lesi adenokarsinoma invasif minimal sampai adenokarsinoma invasif. Patogenesis adenokarsinoma paru berhubungan dengan perubahan genetik beberapa gen, yaitu EGFR, KRAS, ALK, dan ROS1; namun yang paling sering terlibat ialah EGFR, KRAS, dan ALK Imunoterapi yang digunakan untuk terapi adenokarsinoma paru ialah nivolumab, pembrolizumab, atezolizumab, tremelimumab, durvalumab, avelumab, cemiplimab, cetuximab, panitumumab, dan matuzumab; namun terbanyak digunakan ialah nivolumab, pembrolizumab, dan atezolizumab. Simpulan penelitian ini ialah spektrum morfologi dari adenokarsinoma paru berupa lesi preinvasif, adenokarsinoma invasif minimal, dan adenokarsinoma invasif. Patogenesis dari adenokarsinoma paru berhubungan dengan adanya perubahan genetik, terutama mutasi EGFR, KRAS, dan ALK. Imunoterapi yang paling banyak digunakan untuk terapi adenokarsinoma paru ialah nivolumab dan pembrolizumab yang termasuk dalam golongan antibodi PD-1 serta atezolizumab yang masuk dalam golongan antibodi PD-L1.
\end{abstract}

Kata kunci: morfologi adenokarsinoma paru; patogenesis; imunoterapi 


\section{PENDAHULUAN}

Kanker paru merupakan penyebab paling sering kematian terkait kanker di seluruh dunia. ${ }^{1}$ Setiap tahun terdapat lebih dari 8 juta orang di dunia meninggal akibat kanker. ${ }^{2}$ Di Indonesia, berdasarkan data GLOBOCAN (International Agency for Research on Cancer) tahun 2018, terdapat 26.095 orang yang meninggal akibat kanker paru setiap tahunnya, dengan 30.023 kasus baru, tertinggi di Asia Tenggara. ${ }^{3}$ Studi berbasis rumah sakit dari 100 rumah sakit di Jakarta menunjukkan bahwa kanker paru adalah kanker dengan jumlah kasus tertinggi pada pria dan nomor 4 tertinggi pada wanita. Menurut hasil pemeriksaan di laboratorium Patologi Anatomi RSUP Persahabatan tahun 2014, lebih dari 50\% kasus kanker yang didiagnosis adalah kanker paru. ${ }^{4}$

Kanker paru umumnya dibagi dalam dua golongan besar, yaitu karsinoma paru sel kecil (Small Cell Lung Cancer, SCLC) dan karsinoma paru bukan sel kecil (Non-Small Cell Lung Cancer, NSCLC). ${ }^{5}$ Non-Small Cell Lung Cancer selanjutnya dibagi menjadi adenokarsinoma, karsinoma sel skuamosa, dan karsinoma sel besar. ${ }^{6}$ Adenokarsinoma paru merupakan subtipe kanker paru yang paling umum dan paling sering ditemukan. ${ }^{7}$ Diketahui adenokarsinoma dan karsinoma sel skuamosa telah mencapai $60 \%$ dari semua kanker paru. ${ }^{8}$ Beberapa penelitian terbaru di Indonesia dan negara barat menunjukkan bahwa terdapat pergeseran distribusi kanker paru dari karsinoma sel skuamosa menjadi adenokarsinoma. Di Indonesia, lebih dari 70\% kasus kanker paru baru terdiagnosis pada stadium lanjut atau telah mengalami metastasis. ${ }^{9}$ Berdasarkan penelitian yang dilakukan Kasuma tahun 2011, terdapat $45 \%$ adenokarsinoma dan $33 \%$ karsinoma sel skuamosa dari hasil pemeriksaan bronkoskopi 100 pasien kanker paru di Instalasi Diagnostik Terpadu RSUP H. Adam Malik Medan. ${ }^{10}$ Meskipun adenokarsinoma sering ditemukan, identifikasi mikroskopis pada setiap subtipe sering bersifat subjektif dan sulit terutama untuk tumor berukuran kecil yang masih stadium awal atau pada pasien yang memiliki beberapa jenis tumor paru primer. Selain itu, dibutuhkan juga pemahaman tentang patogenesis adenokarsinoma paru karena penting dalam pengobatan kanker paru khususnya terapi target. ${ }^{8}$

Beberapa pengobatan kanker paru telah tersedia saat ini. Pembedahan, terapi radiasi, kemoterapi, dan terapi target merupakan pengobatan umum kanker tetapi banyak terjadi kekambuhan saat terapi. Selain itu, pasien dan dokter juga harus menghadapi berbagai efek samping yang dapat berdampak nyata terhadap kualitas hidup pasien dan pada akhirnya membatasi pilihan pengobatan. ${ }^{2}$ Dalam hal ini, imunoterapi dianggap sebagai teknologi yang memberikan harapan. Perkembangan imunoterapi yang pesat dan hasil penelitian terbaru mendukung keefektifannya dalam pengobatan berbagai tumor termasuk NSCLC. ${ }^{4}$

Berdasarkan latar belakang tersebut, penulis tertarik untuk membahas dan menelaah berbagai informasi ilmiah mengenai morfologi, patogenesis, dan imunoterapi kanker paru tipe adenokarsinoma.

\section{METODE PENELITIAN}

Penelitian ini berbentuk literature review dengan menggunakan tiga database untuk pencarian jurnal yaitu ClinicalKey, PubMed, dan Google Scholar. Pencarian artikel atau jurnal menggunakan kata kunci morphology OR pathogenesis OR immunotherapy AND lung adenocarcinoma dan morfologi $O R$ patogenesis $O R$ imunoterapi $A N D$ adenokarsinoma paru.

Kriteria inklusi dan eksklusi yang digunakan berdasarkan strategi Population, Intervention, Comparison, Outcomes, dan Study (PICOS). Kriteria inklusi untuk populasi ialah kanker paru tipe adenokarsinoma dan untuk outcomes ialah morfologi atau patogenesis atau imunoterapi. Desain penelitian yang digunakan ialah cohort study dan systematic review. Literatur yang dipilih ialah yang dipublikasi dalam lima tahun terakhir (2015-2020), baik dalam bahasa Indonesia maupun bahasa Inggris.

\section{HASIL PENELITIAN}

Terdapat sebanyak 94 artikel yang diperoleh dengan menggunakan ClinicalKey, 
38.935 artikel menggunakan PubMed, dan 52.709 artikel menggunakan Google Scholar $(\mathrm{n}=91.738)$ yang sesuai dengan kata kunci tersebut. Dari hasil pencarian yang didapatkan dilakukan skrining untuk artikel yang dapat diakses berdasarkan rentang waktu tahun 2015-2020 dan didapatkan 11.322 artikel. Kemudian dilakukan skrining berdasarkan abstrak dan fulltext dan didapatkan 5.971 artikel. Selanjutnya dilakukan skrining berdasarkan kriteria judul yang sesuai dengan tema literature review dan didapatkan 213 artikel. Kemudian diperiksa duplikasi dan artikel fulltext yang dapat diakses, sehingga dilakukan review terhadap 20 artikel.

Setelah melalui tahap seleksi studi, didapatkan 20 literatur yang memenuhi kriteria inklusi dan ekslusi, terdiri dari tujuh literatur membahas tentang morfologi adenokarsinoma paru, lima literatur membahas tentang patogenesis adenokarsinoma paru, dan delapan literatur membahas tentang imunoterapi adenokarsinoma paru.

Literatur yang dikaji memiliki perbedaan dan persamaan gambaran hasil telaah. Identifikasi dilakukan berdasarkan hasil penelitian masing-masing literatur pada tabel hasil pencarian literatur yang dikelompokkan berdasarkan morfologi (Tabel 1), patogenesis (Tabel 2), dan imunoterapi (Tabel 3) kanker paru tipe adenokarsinoma.

Tabel 1. Hasil pencarian literatur berdasarkan morfologi kanker paru tipe adenokarsinoma

\begin{tabular}{|c|c|c|c|c|}
\hline $\begin{array}{c}\text { Peneliti/ } \\
\text { Tahun }\end{array}$ & Judul Penelitian & $\begin{array}{c}\text { Metode } \\
\text { Penelitian }\end{array}$ & $\begin{array}{l}\text { Jumlah } \\
\text { Sampel }\end{array}$ & Morfologi \\
\hline $\begin{array}{l}\text { Bian T et al, } \\
2019^{11}\end{array}$ & $\begin{array}{l}\text { Lepidic component at tumor } \\
\text { margin: an independent prog- } \\
\text { nostic factor in invasive lung } \\
\text { adenocarcinoma }\end{array}$ & Cohort study & 276 & $\begin{array}{l}\text { Lepidik, asinar, papiler, mikropapiler, dan } \\
\text { solid. }\end{array}$ \\
\hline $\begin{array}{l}\text { Tang M et } \\
\text { al, } 2019^{12}\end{array}$ & $\begin{array}{l}\text { Electronic-cigarette smoke in- } \\
\text { duces lung adenocarcinoma } \\
\text { and bladder urothelial hyper- } \\
\text { plasiain mice }\end{array}$ & Cohort study & 85 & $\begin{array}{l}\text { Terdapat gambaran adenokarsinoma paru } \\
\text { pada mencit yang terpapar E-cig smoke } \\
(E C S)\end{array}$ \\
\hline $\begin{array}{l}\text { Monroig- } \\
\text { Bosque PC } \\
\text { et al, } 2019^{13}\end{array}$ & $\begin{array}{l}\text { Micropapillary adenocarcino- } \\
\text { ma of lung: morphological } \\
\text { criteria and diagnostic repro- } \\
\text { ducibility among pulmonary } \\
\text { pathologists }\end{array}$ & Cohort study & 30 & $\begin{array}{l}\text { Adenokarsinoma mikropapiler: terdapat } \\
\text { sel-sel kolumnar, sarang sel tipis meman- } \\
\text { jang, retraksi stroma yang luas, pemben- } \\
\text { tukan lumen dengan berkas epitel inter- } \\
\text { nal, bentuk epitel seperti signet ring, va- } \\
\text { kuolisasi intrasitoplasma, banyak sarang } \\
\text { di ruang alveolar yang sama, ruang } \\
\text { lakunar back-to-back, anastomosis epitel, } \\
\text { pleomorfisme yang ditandai, inti yang } \\
\text { berorientasi perifer, dan inti yang menye- } \\
\text { bar secara acak. }\end{array}$ \\
\hline $\begin{array}{l}\text { Hutchinson } \\
\text { BD et al, } \\
2018^{14}\end{array}$ & $\begin{array}{l}\text { Spectrum of lung adeno- } \\
\text { carcinoma }\end{array}$ & $\begin{array}{l}\text { Systematic } \\
\text { review }\end{array}$ & - & $\begin{array}{l}\text { Lesi preinvasif: atypical adenomatous } \\
\text { hyperplasia (AAH), adenocarcinoma in } \\
\text { situ (AIS) } \\
\text { Adenokarsinoma invasif minimal: mini- } \\
\text { mally invasive adenocarcinoma (MIA) } \\
\text { Adenokarsinoma invasif: lepidik, asinar, } \\
\text { papiler, mikropapiler, dan solid }\end{array}$ \\
\hline $\begin{array}{l}\text { Grossman K } \\
\text { et al, } 2016^{15}\end{array}$ & $\begin{array}{l}\text { Hepatoid adenocarcinoma of } \\
\text { the lung: review of a rare form } \\
\text { of lung cancer }\end{array}$ & $\begin{array}{l}\text { Systematic } \\
\text { review }\end{array}$ & - & $\begin{array}{l}\text { Adenokarsinoma hepatoid: berupa gam- } \\
\text { baran asinar atau adenokarsinoma papi- } \\
\text { ler. Beberapa tumor memiliki komponen } \\
\text { sel cincin dan karsinoma neuroendokrin, } \\
\text { bukan adenokarsinoma. }\end{array}$ \\
\hline $\begin{array}{l}\text { Cohen JG et } \\
\text { al, } 2016^{16}\end{array}$ & $\begin{array}{l}\text { Lung adenocarcinomas: corre- } \\
\text { lation of computed tomo- } \\
\text { graphy and pathology findings }\end{array}$ & $\begin{array}{l}\text { Systematic } \\
\text { review }\end{array}$ & - & $\begin{array}{l}\text { Lesi preinvasif: atypical adenomatous } \\
\text { hyperplasia (AAH), adenocarcinoma in } \\
\text { situ (AIS) } \\
\text { Adenokarsinoma invasif minimal: Mini- }\end{array}$ \\
\hline
\end{tabular}


MoralesOyarvide V et al, $2016^{17}$
Tumor islands and spread through air spaces: Distinct patternsof invasion in lung adenocarcinoma mally Invasive Adenocarcinoma (MIA) Adenokarsinoma invasif

Systematic - Minimally invasive adenocarcinoma review (MIA): infiltrasi stroma dan infiltrasi pembuluh darah atau struktur sekitarnya seperti pleura visceral

Tabel 2. Hasil pencarian literatur berdasarkan patogenesis kanker paru tipe adenokarsinoma

\begin{tabular}{|c|c|c|c|}
\hline $\begin{array}{c}\text { Peneliti/ } \\
\text { Tahun }\end{array}$ & Judul penelitian & $\begin{array}{l}\text { Metode } \\
\text { penelitian }\end{array}$ & Patogenesis \\
\hline $\begin{array}{l}\text { Kadara H et } \\
\text { al, } 2016^{18}\end{array}$ & $\begin{array}{l}\text { Early events in the molecular } \\
\text { pathogenesis of lung cancer }\end{array}$ & $\begin{array}{l}\text { Systematic } \\
\text { review }\end{array}$ & $\begin{array}{l}\text { Jalur molekuler yang terlibat dalam proses terjadi- } \\
\text { nya adenokarsinoma paru, yaitu Kirsten rat sarcoma } \\
\text { viral oncogene (KRAS) dan epidermal growth } \\
\text { factor receptor (EGFR) }\end{array}$ \\
\hline $\begin{array}{l}\text { Zhao J et al, } \\
2017^{19}\end{array}$ & $\begin{array}{l}\text { Functional analysis reveals that } \\
\text { RBM10 mutations contribute to } \\
\text { lung adenocarcinoma pathoge- } \\
\text { nesis by deregulating splicing }\end{array}$ & $\begin{array}{l}\text { Systematic } \\
\text { review }\end{array}$ & $\begin{array}{l}\text { Mutasi RBM } 10 \text { berkontribusi pada adenokarsinoma } \\
\text { paru melalui mutasi genetik dan sub-sequent } \\
\text { splicing deregulation }\end{array}$ \\
\hline $\begin{array}{l}\text { Black RC et } \\
\text { al, } 2015^{20}\end{array}$ & $\begin{array}{l}\text { NSCLC: An update of driver } \\
\text { mutations, their role in patho- } \\
\text { genesis and clinical significance }\end{array}$ & $\begin{array}{l}\text { Systematic } \\
\text { review }\end{array}$ & $\begin{array}{l}\text { EGFR: mutasi di daerah kinase dan menyebabkan } \\
\text { fosforilasi yang tidak diatur dan aktivasi jalur } \\
\text { kelangsungan hidup sel / jalur proliferasi. } \\
\text { ALK: meningkatkan pertumbuhan/proliferasi sel } \\
\text { dan menghambat apoptosis di awal. } \\
\text { ROS1: mendorong proliferasi dan menghambat } \\
\text { apoptosis, mengembangkan mutasi melalui penata- } \\
\text { an ulang yang mengarah pada produksi protein fusi } \\
\text { yang tidak diatur yang mempertahankan domain } \\
\text { kinase }\end{array}$ \\
\hline $\begin{array}{l}\text { Chang Y et } \\
\text { al, } 2015^{21}\end{array}$ & $\begin{array}{l}\text { Pathway-based gene signatures } \\
\text { predicting clinical outcome of } \\
\text { lung adenocarcinoma }\end{array}$ & $\begin{array}{l}\text { Systematic } \\
\text { review }\end{array}$ & $\begin{array}{l}\text { Jalur pensinyalan HMGB } 1 \text { memainkan peran utama } \\
\text { dalam tumorigenesis }\end{array}$ \\
\hline $\begin{array}{l}\text { Caetano MS } \\
\text { et al, } 2018^{22}\end{array}$ & $\begin{array}{l}\text { Sex specific function of epithelial } \\
\text { STAT3 signaling in pathogenesis } \\
\text { of } K \text {-ras mutant lung cancer }\end{array}$ & $\begin{array}{l}\text { Systematic } \\
\text { review }\end{array}$ & $\begin{array}{l}\text { Tidak adanya STAT3 epitel pada pria mendorong } \\
\text { tumorigenesis paru melalui peningkatan pensinyal- } \\
\text { an IL-6 dan inflamasi neutrofilik, yang dibatasi oleh } \\
\text { pensinyalan estrogen pada wanita }\end{array}$ \\
\hline
\end{tabular}

Tabel 3. Hasil pencarian literatur berdasarkan imunoterapi kanker paru tipe adenokarsinoma

\begin{tabular}{|c|c|c|c|c|}
\hline $\begin{array}{c}\text { Peneliti/ } \\
\text { Tahun }\end{array}$ & Judul penelitian & $\begin{array}{c}\text { Metode } \\
\text { penelitian }\end{array}$ & $\begin{array}{l}\text { Jumlah } \\
\text { Sampel }\end{array}$ & Imunoterapi \\
\hline $\begin{array}{l}\text { Han L et } \\
\text { al, } 2020^{23}\end{array}$ & $\begin{array}{l}\text { Gene signature based on } B \\
\text { cell predicts clinical outcome } \\
\text { of radiotherapy and immuno- } \\
\text { therapy for patients with lung } \\
\text { adenocarcinoma }\end{array}$ & $\begin{array}{c}\text { Cohort } \\
\text { study }\end{array}$ & 423 & TILBSig \\
\hline $\begin{array}{l}\text { Moya- } \\
\text { Horno I } \\
\text { et al, } \\
2018^{24}\end{array}$ & $\begin{array}{l}\text { Combination of immuno- } \\
\text { therapy with targeted thera- } \\
\text { pies in advanced non-small } \\
\text { cell lung cancer (NSCLC) }\end{array}$ & $\begin{array}{l}\text { Systematic } \\
\text { review }\end{array}$ & - & $\begin{array}{l}\text { Saat ini tiga obat (nivolumab, pembrolizumab } \\
\text { dan atezolizumab) disetujui untuk pengaturan } \\
\text { lini kedua setelah kemoterapi berbasis plati- } \\
\text { num. Pembrolizumab diindikasikan sebagai } \\
\text { terapi tunggal dan terapi kombinasi untuk } \\
\text { pasien tertentu dengan NSCLC lanjut. }\end{array}$ \\
\hline $\begin{array}{l}\text { Chalela } \\
\text { R et al, } \\
2017^{25}\end{array}$ & $\begin{array}{l}\text { Lung adenocarcinoma: from } \\
\text { molecular basis to genome- } \\
\text { guided therapy and immuno- } \\
\text { therapy }\end{array}$ & $\begin{array}{l}\text { Systematic } \\
\text { review }\end{array}$ & - & $\begin{array}{l}\text { Tremelimumab, pada stadium lanjut NSCLC } \\
\text { menunjukkan profil tolerabilitas yang baik. } \\
\text { Pembrolizumab, sebelumnya disebut lambroli- } \\
\text { zumab, ialah imunoglobulin IgG4 dengan } \\
\text { afinitas tinggi untuk PD-1. }\end{array}$ \\
\hline Marrone & Immunotherapy & Systematic & - & Nivolumab, dikaitkan dengan kemanjuran yang \\
\hline
\end{tabular}


KA et al, cancer: no longer an abstract review

$2016^{26}$ concept

lebih besar di semua karakteristik dasar, termasuk ekspresi PD-L1 pada sel tumor (1\%, 5\%, dan 10\%), antibodi: antibodi PD-L1 anti manusia monoklonal kelinci.

Pembrolizumab, antibodi monoklonal IgG4 anti-PD-1 pada manusia.

Atezolizumab, antibodi IgG1 anti-PD-L1 dengan afinitas tinggi, telah dievaluasi dalam studi besar, fase I, penemuan dosis pada tumor padat lanjut dan studi fase II pada NSCLC.

Durvalumab, penghambat IgG1-kappa PD-L1, label terbuka, eskalasi fase I.

Pramono Efek aktivasi programmed $\mathrm{M}$ et al, death ligand 1 (PD-L1) pada review $2019^{27}$ adenokarsinoma paru

Systematic - Pembrolizumab, imunoterapi anti-PD-1 yang menjadi obat lini pertama pada NSCLC dengan ekspresi PD-L1 kuat.

Durvalumab, antibodi monoklonal immuneglobulin G1 kappa bekerja dengan menghambat ikatan PD-L1 dan PD-1.

Nivolumab dan atezolizumab, terapi lini kedua pada NSCLC stadium lanjut.

Saito M

et al,

$2017^{28}$

Santarpia

$\mathrm{M}$ et al,

$2020^{29}$

Ruiz-

Cordero

$\mathrm{R}$ et al,

$2020^{30}$
Treatment of lung adenocarcinoma by moleculartargeted therapy and immunotherapy

Non-small-cell lung cancer signaling pathways, metabolism, and PD-1/PD-L1 antibodies

Targeted therapy and checkpoint immunotherapy in lung cancer
Systematic

review

Systematic review

Systematic review
Antibodi PD 1: Pembrolizumab, Nivolumab

Antibodi PD-L1: Atezolizumab

Pembrolizumab, Nivolumab, Atezolizumab, Durvalumab, Avelumab, Cemiplimab

Antibodi PD 1: Nivolumab
Antibodi PD-L1: Atezolizumab, Durvalumab
EGF/EGFR: Cetuximab, Panitumumab, Matu-
zumab

\section{BAHASAN
Morfologi kanker paru tipe adenokarsi- noma

Hasil penelitian ini menunjukkan bahwa morfologi adenokarsinoma paru ditandai dengan adanya lesi yang terdiri dari spektrum morfologi mulai dari lesi preinvasif, adenokarsinoma invasif minimal sampai adenokarsinoma invasif. Hal ini sesuai dengan studi yang dilakukan oleh Hutchinson et al ${ }^{14}$ dan Cohen et al. ${ }^{16}$ Lesi preinvasif sendiri dibagi menjadi dua, yaitu: atypical adenomatous hyperplasia (AAH) dan adenocarcinoma in situ (AIS). AAH menjadi lesi awal terjadinya suatu adenokarsinoma paru. Biasanya AAH tumbuh di daerah perifer paru dekat pleura dan berukuran kecil, kurang dari $0,5 \mathrm{~cm}$. Selain itu, AAH juga terdiri dari proliferasi lokal sel Clara dan sel-selnya berupa kuboid hingga kolumnar. Sama seperti AAH, AIS juga tumbuh di daerah perifer paru dekat pleura. Ukurannya kurang dari $3 \mathrm{~cm}$ dan umumnya tidak mengandung musin. Pola pertumbuhannya lepidik dan tidak terdapat invasi ke pembuluh darah, limfe, maupun jaringan ikat. ${ }^{31}$

Adenokarsinoma invasif minimal merupakan tumor berbentuk soliter dengan ukuran kurang dari $5 \mathrm{~cm}$, tidak menginvasi pembuluh darah dan limfatik, dengan partum-buhan lepidik. ${ }^{31}$ Studi yang dilakukan oleh Morales-Oyarvide et $\mathrm{al}^{17}$ menunjukkan bahwa adenokarsinoma invasif minimal juga terdapat infiltrasi stroma dan pembuluh darah atau struktur sekitarnya seperti pleura viseral.

Bian et $\mathrm{al}^{11}$ melaporkan bahwa adenokarsinoma invasif sering ditemukan dalam praktik kedokteran, namun mempunyai prognosis yang lebih buruk. ${ }^{11}$ Adenokarsinoma invasif dibagi menjadi lima subtipe, yaitu: lepidik, asinar, papiler, mikropapiler, dan solid. Lepidik merupakan subtipe yang terdiri dari sejumlah sel-sel pneumositik dan 
tumbuh di sepanjang permukaan dinding alveolar. ${ }^{32}$ Lepidik memiliki pola partumbuhan yang lepidik, namun tidak memiliki musin, fokus invasifnya mencakup lebih dari $0,5 \mathrm{~cm}$, dan cenderung lebih baik dibandingkan jenis adenokarsinoma invasif yang lain. ${ }^{27}$ Asinar merupakan subtipe yang menunjukkan mayoritas komponen kelenjar. ${ }^{32}$ Asinar memiliki pola pertumbuhan asinar dan terdapat musin, berbentuk bulat sampai dengan oval. dan terdapat sel tumor yang mengelilingi suatu ruang kosong didalamnya. ${ }^{27}$ Papiler merupakan subtipe yang menunjukkan komponen utama dari pertumbuhan sel kelenjar sepanjang sentral fibrovascular core. ${ }^{32}$ Subtipe papiler berbentuk kuboid atau kolumnar dengan pola pertumbuhan papiler. Pada papiler juga terdapat polarisasi inti. Mikropapiler merupakan subtipe yang ukuran selnya kecil dan berbentuk kuboid, pola pertumbuhannya mikropapiler, dan terdapat fibrovascular core meskipun jarang. ${ }^{27}$ Hasil penelitian Monroig-Bosque et $\mathrm{al}^{13}$ menunjukkan bahwa adenokarsinoma mikropapiler juga terdapat sel-sel kolumnar, sarang sel tipis memanjang, retraksi stroma yang luas, pembentukan lumen dengan berkas epitel internal, bentuk epitel seperti signet ring, vakuolisasi intra-sitoplasma, banyak sarang di ruang alveolar yang sama, ruang lakunar back-to-back, anastomosis epitel, pleomorfisme yang ditandai, inti yang berorientasi perifer, dan inti yang menyebar secara acak. ${ }^{13}$ Subtipe solid terdiri atas sel tumor dengan bentuk poligonal membentuk lembaran yang tidak dikenali, terdapat musin intrasel dengan minimal lima sel tumor pada lapangan pandang kecil, sitoplasma sel jernih dengan inti yang sangat pleomorfik, dan memiliki prognosis yang buruk. ${ }^{27}$

Selain dari jenis-jenis adenokarsinoma yang telah dipaparkan, terdapat juga jenis yang jarang ditemukan, yaitu adenokarsinoma hepatoid. Grossman et al ${ }^{15}$ mengemukakan bahwa adenokarsinoma hepatoid berupa gambaran asinar atau adenokarsinoma papiler, namun beberapa tumor memiliki komponen sel cincin dan karsinoma neuroendokrin, bukan berupa adenokarsinoma. Disebut sebagai adenokarsinoma hepatoid karena gambaran morfologinya yang menyerupai karsinoma hepatoseluler. Pada dasarnya, adenokarsinoma hepatoid identik dengan kanker hati yang terdiri dari sel-sel tumor dengan sitoplasma yang eosinofilik. Prognosis dari adenokarsinoma hepatoid biasanya buruk. ${ }^{15}$

\section{Patogenesis kanker paru tipe adeno- karsinoma}

Hasil penelitian ini menunjukkan bahwa patogenesis adenokarsinoma didasari oleh perubahan genetik. Menurut Kadara et al, ${ }^{18}$ mutasi KRAS dan EGFR ikut terlibat dalam proses terjadinya adenokarsinoma paru. Hal ini sejalan dengan studi yang dilakukan oleh Black et $\mathrm{al}^{20}$ mengenai beberapa mutasi driver seperti EGFR, ALK, dan ROS1.

Mutasi EGFR ini sangat spesifik untuk adenokarsinoma paru. Di antara adenokarsinoma lainnya, mutasi EGFR sering terdeteksi pada kasus dengan pertumbuhan lepidik dan papiler. Perubahan genetik dari gen pemicu kanker paru utama lainnya seperti KRAS, ALK, ROS1, BRAF, RET, dan ERBB2, saling eksklusif dengan mutasi EGFR, mungkin karena ini semua berkumpul pada jalur pensinyalan intrasel yang sama, dan satu gangguan pada jalur ini cukup untuk memicu pembentukan tumor. Mutasi EGFR lebih sering terjadi pada wanita bukan perokok dan berasal dari Timur Jauh, sedangkan mutasi KRAS lebih sering dikaitkan dengan kebiasaan merokok. ${ }^{20}$

Rearrangement ALK pada kanker paru sangat terkait dengan histologi adenokarsinoma, khususnya dengan asinar dan/atau pola pertumbuhan solid atau dengan gambaran seluler signet ring cell carcinoma. Meskipun fusi ALK umum terjadi pada limfoma sel besar anaplastik dan tumor miofibroblastik inflamasi, fusi EML4-ALK spesifik hampir secara eksklusif ditemukan pada kanker paru. ${ }^{20}$

C-ros oncogene 1 (ROS1) merupakan reseptor tirosin kinase yang termasuk dalam keluarga insulin. C-ros oncogene 1 memiliki kemiripan yang mencolok dengan ALK dimana gen ini mendorong proliferasi dan menghambat apoptosis, mengembangkan mutasi melalui rearrangement yang meng- 
arah pada produksi protein fusi yang tidak diatur yang mempertahankan domain kinase, dan terutama menyerang anak muda serta bukan perokok dengan adenokarsinoma. Meskipun mirip dengan ALK dalam banyak hal, perbedaan yang mencolok ialah frekuen-si yaitu ROS1 ditemukan sebanyak $1-2 \%$ dari semua jenis NSCLC. ${ }^{20}$

\section{Imunoterapi kanker paru tipe adeno- karsinoma}

Hasil penelitian ini menunjukkan bahwa jenis obat imunoterapi yang digunakan ialah nivolumab, pembrolizumab, atezolizumab, tremelimumab, durvalumab, avelumab, cemiplimab, cetuximab, panitumumab, dan matuzumab; namun yang paling sering digunakan ialah nivolumab, pembrolizumab, dan atezolizumab. Hal ini sejalan dengan studi yang dilakukan oleh MoyaHorno et al, Chalela et al, Marrone et al, Pramono et al, Saito et al, Santarpia et al, dan Ruiz-Cordero et al. ${ }^{24-30}$

Nivolumab bekerja dengan cara menghalangi interaksi antara PD-1 dan PD-L1, yakni mengikat molekul PD-1 dan menghasilkan penghalang sterik yang mencegah PD-L1 mengikat pada molekul PD-1, mengaktifkan respon imun dari mediasi jalur mediator PD-1, termasuk respon imun antitumor. ${ }^{33}$ Programmed death receptor 1 (PD1) disandi oleh gen PDCD1 pada kromosom 2q37.3 dan diekspresikan pada limfosit $T$ teraktivasi, limfosit $\mathrm{B}$, makrofag, dan sel dendritik. Pada infeksi akut terjadi stimulasi pada $T$ cell receptor (TCR) yang menyebabkan ikatan nuclear factor of activated $T$ cell 1 (NFATc1) dengan regio $\mathrm{CR}-\mathrm{C}$ gen PDCD1. Nuclear factor of activated T cell 1 dibutuhkan untuk induksi PD-1 namun, ekspresi NFATc1 tidak bertahan lama dan segera berkurang setelah induksi. Hal ini disebut sebagai mekanisme umpan balik yang menghambat ekspresi PD-1 pada infeksi akut. Dengan berkurangnya ekspresi PD-1 maka respon imun tubuh dapat bekerja mengeliminasi antigen. Sementara itu, PDL1 yang dikenal sebagai B7-H1 atau CD274 merupakan ligan fungsional dari reseptor PD-1. PD-L1 disandi oleh gen PDCDL1 pada kromosom 9p.24.1. Ekspresi PD-L1 diatur oleh berbagai jalur sinyal onkogenesis. Terdapat beberapa jalur sinyal onkogenesis yaitu jalur RAS/RAF/MEK/ MAPK-ERK, jalur PI3K/PTEN/Akt/ mTOR, dan jalur STAT1/STAT3. Regulasi ekspresi PD-L1 pada adenokarsinoma paru yaitu terdapat mutasi KRAS yang menyebabkan aktivasi faktor transkipsi c-Jun pada regio promoter gen PDCL1. Aktivasi faktor transkripsi akan diikuti oleh proses translasi dan dimodifikasi pascatranslasi dengan $N$ glycosylation. ${ }^{27}$ Bila nivolumab dikombinasikan dengan kemoterapi platinum based (ipilimumab atau erlotinib) cenderung lebih baik daripada hanya nivolumab saja atau kemoterapi umum pada terapi NSCLC tingkat lanjut. ${ }^{33}$

Pembrolizumab atau imunoglobulin (Ig) G4 kappa adalah antibodi monoklonal PD1. Cancer Network and European Society for Medical Oncology guidelines merekomendasikan penggunaan pembrolizumab untuk pengobatan pasien dengan NSCLC stadium lanjut dan ekspresi PD-L1. Melalui jalur PD-1 atau PD-L1, sel tumor dapat memromosikan terjadinya imunosupresi sehingga responnya dapat berupa menghindari aktivitas anti tumor. Pensinyalan penghambatan sel-T dapat terganggu oleh inhibitor PD-1 atau PD-L1, sehingga perlu diaktifkan kembali aktivitas anti tumor sel $\mathrm{T}$ sitotoksik. Terapi kombinasi pembrolizumab dengan kemoterapi lini pertama menunjukkan efek anti tumor yang sangat baik serta mampu meningkatkan angka harapan hidup pada pasien NSCLC stadium lanjut. ${ }^{33}$

Atezolizumab adalah antibodi monoklonal yang berikatan dengan PD-L1 dan berperan menghambat interaksi PD-1 untuk menurunkan aktivitas sel $\mathrm{T}$ terhadap sel tumor. Atezolizumab dapat diberikan sebagai second line atau third line therapy pada pasien NSCLC stadium lanjut. Tingkat harapan hidup pasien sama bila dibandingkan dengan pemberian doksetasel. Atezolizumab juga mempunyai efek samping, yaitu pneumonitis dan peningkatan fungsi hati. ${ }^{33}$

\section{SIMPULAN}

Spektrum morfologi dari adenokarsinoma paru diawali dengan adanya lesi 
preinvasif, adenokarsinoma invasif minimal, dan adenokarsinoma invasif. Patogenesisnya berhubungan dengan adanya perubahan genetik, terutama mutasi EGFR, KRAS, dan ALK. Imunoterapi yang paling banyak digunakan pada adenokarsinoma paru ialah nivolumab dan pembrolizumab yang termasuk dalam golongan antibodi PD-1 serta atezolizumab yang termasuk dalam golongan antibodi PD-L1.

Diharapkan adanya penelitian lanjut tentang adenokarsinoma paru mengingat masih sedikitnya penelitian tersebut di Indonesia dengan menggunakan database yang memiliki fitur lebih lengkap seperti penggolongan tahun, tipe artikel, dan free fulltext untuk mempermudah penyaringan artikel dalam pencarian literatur.

\section{Konflik Kepentingan}

Penulis menyatakan tidak terdapat konflik kepentingan dalam studi ini.

\section{DAFTAR PUSTAKA}

1. Gesthalter YB, Billatos E, Kathuria H. Lung Cancer. Genomic and Precision Medicine: Primary Care (3rd ed). Elsevier Inc., 2017; p. 165-80.

2. Morrissey K, Yuraszeck T, Li CC, Zhang Y, Kasichayanula S. Immunotherapy and novel combinations in oncology: current landscape, challenges, and opportunities. Clin Transl Sci. 2016;9(2):89-104.

3. Bray F, Ferlay J, Soerjomataram I, Siegel RL, Torre LA, Jemal A. Global cancer statistics 2018: GLOBOCAN estimates of incidence and mortality worldwide for 36 cancers in 185 countries. CA Cancer J Clin. 2018;68(6):394-424.

4. Kristianto A, Rahman A. Pembrolizumab sebgai imunoterapi pada nonsmall cell lung carcinoma. Indonesia Journal Chest. 2019;6(2):96-106.

5. Oktaviyanti IK. Mutasi egfr pada pemeriksaan sitologi adenokarsinoma paru. Berk Kedokt. 2015;11(2):213-9.

6. Komite Penanggulangan Kanker Nasional. Pedoman Nasional Pelayanan Kedokteran Kanker Paru. Jakarta: Kementerian Kesehatan Nasional, 2017.

7. $\mathrm{Li} \mathrm{C}, \mathrm{Lu} \mathrm{H}$. Adenosquamous carcinoma of the lung. Onco Targets Ther. 2018;11:482935.
8. Chang HH, Dreyfuss JM, Ramoni MF. A transcriptional network signature characterizes lung cancer subtypes. Cancer. 2011;117:353-60.

9. Putra DH, Wulandari L, Mustokoweni S. Profil penderita kanker paru karsinoma bukan sel kecil (KPKBSK) di RSUD Dr. Soetomo. Juxta. 2016;8(1):30-4.

10. Kasuma D. Profil penderita yang dilakukan tindakan bronkoskopi serat optik lentur di instalasi diagnostik terpadu (IDT) RSUP H. Adam Malik Medan. Repository USU. 2011. Available from: http:// repository.usu.ac.id/handle/ 123456789/17044

11. Bian T, Jiang D, Feng J, Liu J, Qian L, Zhang $\mathrm{Q}$, et al. Lepidic component at tumor margin: an independent prognostic factor in invasive. Hum Pathol. 2021; 83(2019): 106-14.

12. Tang M, Wu X, Lee H, Xia Y, Deng F, Moreira AL. Electronic-cigarette smoke induces lung adenocarcinoma and bladder urothelial hyperplasia in mice. PNAS. 2019;116(43):21727-31.

13. Monroig-bosque PC, Morales-rosado JA, Roden AC, Churg A, Barrios R, Cagle $\mathrm{P}$, et al. Micropapillary adenocarcinoma of lung: morphological criteria and diagnostic reproducibility among pulmonary pathologists. Ann Diagn Pathol. 2021;41(2019):43-50.

14. Hutchinson BD, Shroff GS, Truong MT, Ko JP. Spectrum of lung adenocarcinoma. Semin Ultrasound, CT, MRI. 2021; 40(3):255-64.

15. Grossman K, Beth M, Braman SS. Hepatoid adenocarcinoma of the lung: review of a rare form of lung cancer. Respir Med. 2021;119(2016):175-9.

16. Cohen JG, Reymond E, Jankowski A. Lung adenocarcinomas: correlation of computed tomography and pathology findings. Diagn Interv Imaging. 2021; 97(10):955-63.

17. Morales-Oyarvide V, Mino-Kenudson M. Tumor islands and spread through air spaces: distinct patterns of invasion in lung adenocarcinoma. Pathol Int. 2016; 66(1):1-7.

18. Kadara H, Scheet P, Wistuba II, Spira AE. Early events in the molecular pathogenesis of lung cancer. Cancer Prev Res (Phila). 2016;9(7):518-27.

19. Zhao J, Sun Y, Huang Y, Song F, Huang Z, 
Bao Y, et al. Functional analysis reveals that RBM10 mutations contribute to lung adenocarcinoma pathogenesis by deregulating splicing. Sci Rep. 2017;7: 40488. Doi: https://doi.org/10.1038/ srep40488

20. Black RC, Khurshid H. NSCLC. An update of driver mutations, their role in pathogenesis and clinical significance. R I Med J. 2015;98(10):25-8.

21. Chang Y, Chen C, Chen H, Yang P. Pathwaybased gene signatures predicting clinical outcome of lung adenocarcinoma. Sci Rep. 2015;5:10979. Doi: 10.1038/srep 10979

22. Caetano MS, Hassane M, Van HT, Bugarin E, Cumpian AM, Mcdowell CL, et al. Pathogenesis of K-ras mutant lung cancer. Nat Commun. 2018;9(1):4589.

23. Han L, Shi H, Luo Y, Sun W, Jiang X, Gong $\mathrm{Y}$, et al. Gene signature based on B cell predicts clinical outcome of radiotherapy and immunotherapy for patients with lung adenocarcinoma. Cancer Med. 2020;9(24):9581-94.

24. Moya-Horno I, Viteri S, Karachaliou N, Rosell $\mathrm{R}$. Combination of immunotherapy with targeted therapies in advanced nonsmall cell lung cancer (NSCLC). Ther Adv med Oncol. 2018;10:175883401 7745012.

25. Chalela R, Curull V, Enríquez C, Pijuan L, Bellosillo B, Gea J. Lung adenocarcinoma: from molecular basis to genomeguided therapy and immunotherapy. J Thorac Dis. 2017;9(7):2142-58.

26. Marrone KA, Naidoo J, Brahmer JR. Immuno- therapy for lung Cancer: no longer an abstract concept. Semin Respir Crit Care Med. 2016;37(5):771-82.

27. Pramono M, Saraswati M, Zuraidah E. Efek aktivasi programmed death ligand 1 (PD-L1) pada adenokarsinoma paru. Pratista Patologi. 2019;6(2).

28. Saito M, Suzuki H, Kono K, Takenoshita S. Treatment of lung adenocarcinoma by molecular-targeted therapy and immunotherapy. Surg Today. 2017;0(0):0.

29. Santarpia M, Aguilar A, Chaib I, Cardona AF, Fancelli S, Laguia F, et al. Nonsmall-cell lung cancer signaling pathways, metabolism, and PD-1/PD-L1 anti-bodies. Cancers (Basel). 2020; 12(6): 1475 .

30. Ruiz-cordero R, Devine WP. Targeted therapy and checkpoint immunotherapy in lung cancer. Surg Pathol. 2021;13(1):17-33.

31. Lay FK, Zuraidah E, Billianti YD, Lay FK, Lay FK, Zuraidah E, et al. Gambaran klinik, histopatologik, dan molekuler fusi gen RET (Rearranged During Transfection ) pada adenokarsinoma paru. Pratista Patologi. 2019;6(1).

32. Hutabarat HA. Hubungan berbagai karakteristik penderita adenokarsinoma paru dengan status mutasi epidermal growth factor receptor (EGFR) di RSUP Haji Adam Malik Medan tahun 2015-2017 [Tesis]. Medan: Fakultas Kedokteran Universitas Sumatera Utara; 2018.

33. Andayani N, Julisafrida L. Peranan immunoterapi pada kanker paru. J Kedokt Syiah Kuala. 2020;20(2):70-7. 